\title{
Students from the Russian Federation at Polish universities
}

\section{Krystyna Gomółka}

\author{
Dr hab., prof. Nadzw, Managament and Economics Faculty, Gdańsk Technical University of Technology
} ul. Gabriela Narutowicza 11/12, 80-233 Gdańsk; kgom@zie.pg.gda.p

\section{Doi:10.5901/mjss.2015.v6n6s5p358}

\begin{abstract}
Since the dissolution of the USSR, students from the Russian Federation have been able to study at Polish universities on the basis of bilateral agreements between the Polish and Russian governments. The purpose of this article is to analyse the legal basis enabling Russian citizens to obtain education in Poland, analyse the numbers of such students and the principles and procedure they followed to begin studies at Polish universities in 1993-2014. Throughout the period investigated, students from Russia accounted for a small percentage of foreigners entering Polish universities, ranging between $1.02 \%$ and $2.03 \%$ of the overall number of foreigners coming to study in Poland. At the beginning of the period investigated, in the academic year 1993/1994 all Russian citizens studying in Poland were Polish government scholarship holders, whereas in the last year analysed scholarship holders accounted for more than $10 \%$ of the overall number of students. The predominant group of students were those paying for their studies (more than 64\%) and those studying without a scholarship and free of charge (23\%). The most popular subjects included Management, Economics, International Relationships, Journalism, Political Sciences and Eastern Studies. Students from the Russian Federation entered the largest Polish universities: Warsaw University, Jagiellonian University, University in Poznań, University of Wrocław, University of Lublin and University of Białystok.
\end{abstract}

Keywords: Russian Federation, students, education, Poland, universities

\section{Introduction}

Since the early 1990s students from the Russian Federation have not been among the most numerous groups of foreigners entering higher education in Poland. Their recruitment to university studies, art-related placements, specialist training programmes and postgraduate placements consisted of several stages: from the university's approval, through the entry of the territory of Poland and legalisation of stay to undertaking education in Poland. Those undertaking studies could take advantage of the scholarships offered or use their own resources. The purpose of this article is to present the legal basis enabling citizens of the Russian Federation to study in Poland, to analyse their numbers and the principles and procedure they follow when undertaking studies at Polish universities. The research hypothesis is as follows: the range of scholarships offered has not contributed to an increase in the number of students from Russia entering Polish universities. To test this hypothesis, the author formulated the following research questions: $1 /$ What was the legal basis for the arrival of students from the Russian Federation wishing to study at Polish universities?; 2/ Which universities and subjects did they choose most often?; 3/ What scholarships were available to them?; 4/ What proportion of students took advantage of the scholarships offered?; 5/Did the scholarships offered contribute to an increased number of students entering education at Polish universities? The author used the following research methods: analysis of source materials, comparative analysis and statistical data analysis. This study was completed on the basis of data from the Bureau for Academic Recognition and International Exchange, Central Statistical Office, legal acts and sparse specialist literature available.

\section{Legal Acts Enabling Education}

The relationships between the Russian Federation and European Communities are regulated by the Act of 24 June 1994. When the Act on partnership and cooperation was signed, which entered into force on 01 December 1997, Poland became party to that agreement after 01 May 2004 (Szymański, 2015). As part of their bilateral relations, Poland entered into a Treaty with the Russian Federation on 22 May 1992. In Article 13(1) the parties declared theirs support to cooperation in culture, science, education and higher education on the principles set out in UNESCO conventions, CSCE documents and in bilateral agreements. Section 7 of the Treaty provided for the exchange of students, doctoral candidates and scholarship holders. Certificates of completion of primary and secondary education as well as university 
diplomas confirming the award of academic titles and degrees were considered equivalent (Journal of Laws of 1993 No. 61). Certificates, diplomas and academic degrees and titles obtained at Russian universities before 25 September 2005 could be recognised pursuant to the Prague Convention of 1972 (Journal of Laws of 1973 No. 5) and the Agreement of May 1974 on the recognition of degrees and titles between the Soviet Union and Polish People's Republic with the exception of education and degrees in the field of medicine and architecture (Journal of Laws of 1975, No. 4). After 25 September 2005 the equivalence of education could only be confirmed through the recognition process.

In August 1993 the agreement on academic, cultural and educational cooperation was signed. Academic cooperation was referred to in Articles 14-20, which described the activities undertaken as part of cooperation between universities and scientific institutions on the basis of plans, programmes and agreements. The agreement provided for the exchange of academic teachers, students and doctoral candidates, enabling them to raise their qualifications (Journal of Laws of 1994, No. 36). Detailed rules concerning the educational and academic exchange were set out in the Arrangement of October 2005 between the Ministry of National Education of the Republic of Poland and the Ministry of Science and Education of the Russian Federation on educational cooperation concluded for a period of three years with the option of automatic extension for another 3 years. The agreement guarantees 60 person-months of grants for academic training of academic and teaching staff as well as doctoral candidates. The exchange participants received grants from the Polish side (Scholarship offer of the Bureau for Academic Recognition and International Exchange, 2012). Exchange of students of art universities was regulated in the protocol of cooperation of the ministers of culture of both states (Official Gazette of the Republic of Poland (M. P.) of 2003, No. 8).

In the early 1990s Russian citizens entered Polish universities because they were able to move freely across the Polish border, without a visa granting the right to study. The situation began to change in mid-1990s, when Polish authorities started to enforce the law in that respect. Article 16 of the Regulation of 2002 on starting and completing of studies and training by foreign nationals and their participation in research and development activities provided for the possibility of suspending the scholarship of a foreign student who did not have a valid visa or residence card (Journal of Laws of 2002, No. 69). The institution responsible for the exchange of students, trainees and doctoral candidates was the Bureau for Academic Recognition and International Exchange (BUWIM). The conclusion of the Schengen Agreement and Poland's inclusion in the EU structures altered the status of students from the Russian Federation. The matters related to the education of foreign nationals in Poland were regulated by the provisions of Article 43 of the Higher Education Act of 27 July 2005 (Journal of Laws of 2005, No. 164), whereunder foreigners could study on the same terms as Polish citizens or on a different basis. The former option applied to foreigners holding a valid Pole's Card and having: a permit to settle in the territory of Poland or the right of permanent residence, with the status of refugee granted by the Republic of Poland, under temporary or supplementary protection or holding a temporary residence permit. Such students can apply for maintenance grants, grants for disabled persons, financial aid, rector's scholarship for outstanding students or scholarships awarded by the relevant ministers for academic or sports achievements. The scholarships and grants are awarded on the basis of the Government Programme of Cooperation with the Polish Diaspora and Poles Abroad. Candidates for scholarships are entered by diplomatic posts or institutions from the respective countries, responsible for student exchange.

Detailed provisions regulating the matter of foreign nationals entering education on the terms and basis other than those applicable to Polish citizens, stated in Article 43 paragraph 3 and Article 4 of the aforementioned Act, are specified in the Regulation of the Minister of Science and Higher Education of 12 October 2006 on starting and completing of studies and training by foreign nationals and their participation in research and development activities and the Regulation of the Minister of Science and Higher Education of 09 September 2009 (Journal of Laws of 2009, No. 176).

Foreign students receive education free of charge or without a scholarship on the basis of assistance programmes offered to certain countries, including the Russian Federation, by the Polish government via appropriate institutions or Polish diplomatic posts. Other citizens of Belarus may enter university education in Poland at a charge. The minimum tuition fee is EUR 2000 per year; this amount may vary between the universities.

Poland does not have just one document regulating all matters concerning admission of foreign students in a consistent and comprehensive manner. Selected proposals regarding foreign students are contained in the Human Capital Development Strategy, specifying the number of students allowed to study in Poland by 2020 (Official Gazette of the Republic of Poland (M. P.) of 2013, item 376) and in the document adopted by the Council of Ministers in July 2012 "Poland's migration policy - status quo and proposed actions" where foreign students were referred to as one of the priorities. The issues concerning students of Polish descent are addressed by annual strategic plans of cooperation with Poland and Poles residing abroad, referring to educating young people in specialisations in demand in their countries of residence, supporting scholarship programmes and promotion of education in Poland (Plan of Cooperation with the Polish Diaspora and Poles Abroad, 2013). 
The situation of foreign students in Poland was improved by the Act of 12 December 2013 on foreign nationals, which extended the term of temporary residence permits (Journal of Laws of 2013, item 1650). Pursuant to the Act, firstyear foreign students are issued with residence permits for a period of 15 months, and foreign nationals on a scholarship of less than 12 months - for a period of an academic year plus three months. Meanwhile, students starting the second year of study or subsequent years receive a temporary residence permit for up to 3 years. This way, they may avoid being struck off the list of students if they fail an examination or their residence card is cancelled. The Act also provides the graduates of Polish universities with the possibility of applying for a temporary residence permit for a period of one year to seek employment.

\section{Characteristics of Students from Russia}

Russian citizens have been coming to Poland to study since the early 1990s. The statistics provided by the Bureau for Academic Recognition and International Exchange indicate the following numbers of students from the former Soviet Republics in the respective academic years: 1989/1990 - 135, 1990/1991 - 342 and 1991/1992 - 684 persons (Małyszko, 2005). The Office did not keep detailed statistics with indication of the country of origin until the academic year 1993/1994. Table 1 shows the number of Russian students in the overall population of foreigners studying in Poland.

Table 1. Number of students from the Russian Federation in 1993-2014

\begin{tabular}{|c|c|c|c|}
\hline Academic year & Total number of students & Number of students from the Russian Federation & of total foreign students \\
\hline $1993 / 1994$ & 4968 & 51 & 1.02 \\
\hline $1994 / 1995$ & 5176 & 98 & 1.89 \\
\hline $1995 / 1996$ & 5202 & 89 & 1.71 \\
\hline $1996 / 1997$ & 5313 & 98 & 184 \\
\hline $1997 / 1998$ & 5443 & 103 & 1.89 \\
\hline $1998 / 1999$ & 5541 & 112 & 2.02 \\
\hline $1999 / 2000$ & 6025 & 138 & 2.29 \\
\hline $2000 / 2001$ & 6669 & 200 & 1.29 \\
\hline 20012002 & 7380 & 199 & 2.28 \\
\hline $2002 / 2003$ & 7608 & 442 & 2.69 \\
\hline $2003 / 2004$ & 8160 & 458 & 5.61 \\
\hline $2004 / 2005$ & 8826 & 380 & 4.30 \\
\hline $2005 / 2006$ & 10092 & 467 & 4.62 \\
\hline $2006 / 2007$ & 11752 & 386 & 3.28 \\
\hline $2007 / 2008$ & 13695 & 284 & 2.07 \\
\hline $2008 / 2009$ & 15862 & 374 & 2.35 \\
\hline $2009 / 2010$ & 17000 & 387 & 2.27 \\
\hline $2010 / 2011$ & 24474 & 409 & 1.67 \\
\hline $2011 / 2012$ & 24253 & 508 & 2.07 \\
\hline $2012 / 2013$ & 29172 & 616 & 2.11 \\
\hline $2013 / 2014$ & 35983 & 734 & 2.03 \\
\hline
\end{tabular}

Source: Own work based on the study titled "Universities and their finances". Central Statistical Office (GUS) 1997-2014, Warsaw 1998-2015.

The data presented in Table 1 suggest that the number of students arriving from the Russian Federation was increasing since the academic year 1993/1994. The most significant rise in their number was observed after 2000, shortly before Poland's accession to the European Union structures. Russian students accounted for a only a small percentage of the overall number of foreign nationals taking up studies in Poland. They constituted 1.02\% in the academic year 1993/1994 and $2.03 \%$ in the academic year $2013 / 2013$. Nearly $100 \%$ of students from the Russian Federation took up full-time studies. They mostly studied for a bachelor's degree (first-tier studies) at public universities. Very rarely did they enter technical or medical universities. The requirements concerning the award of scholarships were often the decisive factor in their choice of subjects. The most popular subjects included Management, International Relationships, Administration, Journalism, Economics, Political Sciences and Eastern Studies. The foreign nationals took up studies at the largest and best Polish universities: the University of Warsaw, the Jagiellonian University, University of Wrocław, Adam Mickiewicz University, Maria Curie-Skłodowska University and the University of Białystok. 


\section{Procedure for and Principles Concerning University Entry}

Since the beginning of the 1990s students from the Russian Federation were able to study at Polish universities, receiving scholarships, free of charge and without scholarships or at a charge. The number of scholarships awarded by the Polish government was increasing, since the process was perceived as implementation of the country's foreign policy of revival of Polish intelligentsia, also that from the Russian Federation, in the East (Wyszyński, 2011). It was assumed that the graduates would return to their countries and take up employment there. Table 2 indicates the numbers of scholarship holders from the Russian Federation studying free of charge and at a charge in 1993-2014.

Table 2. Scholarship holders from the Russian Federation studying free of charge and at a charge in 1993-2014.

\begin{tabular}{|c|c|c|c|c|c|}
\hline $\begin{array}{c}\text { Academic } \\
\text { year }\end{array}$ & $\begin{array}{l}\text { Overall number of } \\
\text { students }\end{array}$ & $\begin{array}{l}\text { RP scholarship } \\
\text { holders }\end{array}$ & $\begin{array}{c}\text { Other } \\
\text { scholarships }\end{array}$ & $\begin{array}{l}\text { Free of charge and without } \\
\text { scholarship }\end{array}$ & $\begin{array}{c}\text { At a } \\
\text { charge }\end{array}$ \\
\hline $1993 / 1994$ & 51 & 51 & & 0 & 0 \\
\hline 1994/1995 & 98 & 96 & 0 & 2 & 0 \\
\hline $1995 / 1996$ & 89 & 76 & 0 & 13 & 0 \\
\hline 1996/1997 & 98 & 81 & 0 & 17 & 0 \\
\hline 1997/1998 & 103 & 86 & 0 & 17 & 0 \\
\hline 1998/1999 & 112 & 84 & 0 & 28 & 0 \\
\hline $1999 / 2000$ & 138 & 119 & 0 & 19 & 0 \\
\hline $2000 / 2001$ & 200 & 40 & 0 & 17 & 143 \\
\hline $2001 / 2002$ & 199 & 152 & 0 & 43 & 4 \\
\hline $2002 / 2003$ & 442 & 176 & 0 & 247 & 19 \\
\hline $2003 / 2004$ & 458 & 157 & 0 & 286 & 15 \\
\hline $2004 / 2005$ & 380 & 141 & 0 & 203 & 36 \\
\hline $2005 / 2006$ & 467 & 146 & 0 & 266 & 49 \\
\hline $2006 / 2007$ & 386 & 125 & 7 & 166 & 88 \\
\hline $2007 / 2008$ & 284 & 112 & 0 & 92 & 80 \\
\hline $2008 / 2009$ & 374 & 97 & 1 & 179 & 97 \\
\hline $2009 / 2010$ & 387 & 92 & 17 & 128 & 150 \\
\hline $2010 / 2011$ & 409 & 80 & 14 & 131 & 184 \\
\hline $2011 / 2012$ & 508 & 87 & 10 & 147 & 264 \\
\hline $2012 / 2013$ & 616 & 98 & 12 & 143 & 363 \\
\hline $2013 / 2014$ & 734 & 77 & 9 & 171 & 477 \\
\hline
\end{tabular}

Source: Own elaboration based on materials from the Bureau for Academic Recognition and International Exchange

The data presented in Table 2 suggest that the 51 students who entered Polish universities in 1993/1994 were grantees of the Polish government. In subsequent years, the overall number of students was increasing, but only a small part of them received scholarships, which was due to the policy of awarding grants to persons of Polish descent. At the end of the period investigated, in the academic year 2013/2014, of the 734 Russian students entering Polish universities only 77 (10.4\%) received scholarships. Polish government grants were awarded, inter alia, as part of the Konstanty Kalinowski Scholarship Programme, scholarships for students of Specialist Eastern Studies and Stanisław Grabski Scholarship Programme for students of economic subjects. The Ministry of Foreign Affairs in cooperation with "Wspólnota Polska" Association awarded scholarships to young people of Polish receiving education in Poland in the framework of the Programme of Cooperation with the Polish Diaspora and Poles Abroad and from Cardinal Stefan Wyszyński Scholarship Fund. The number of scholarships increased since the academic year 2004/2005, coinciding with Poland's entry into the EU structures, and then after the creation of the Eastern Partnership. It was then that the Polish ministers for higher education and science and foreign affairs established new scholarship programmes for citizens of countries included in that initiative. The number of scholarships was increased thanks to funds from the Programme for students of Specialist Eastern Studies, Stefan Banach Scholarship Programme initiated in 2013 at Warsaw University (Stypendia dla studentów z krajów Partnerstwa Wschodniego, 2013). The programme was aimed at students undertaking two-year postgraduate studies of natural and economical sciences, engineering, European studies and European law at public universities. The available scholarship programmes for those starting university education were presented on websites of Polish diplomatic posts in Russia. In the second half of the first decade of the 21st century the governmental scholarships were 
supplemented by the so-called other scholarships. Those usually consisted of one-off or long-term grants awarded by individuals or institutions to persons beginning studies of a subject specified by the grantor. They were awarded to undergraduate students and those doing supplementary, uniform and doctoral studies. One of the best-known schemes is the Lane Kirkland Scholarship Programme. In the first, pilot year it was participated by only 12 Ukrainians. The operator of the 2001/2002 edition became the Polish-American Fulbright Programme and scholarships were available to students from Belarus, the Russian Federation (only from the Kaliningrad Oblast), Slovakia and Lithuania. In 2000-2015 scholarships were awarded to 40 Russian Federation citizens (Lane Kirkland Scholarship Programme, 2015). Most of the scholarships were received by students of Economy and Management, Law, Public Administration, Journalism and Political Science, whereas students of Agriculture, Health Studies and Insurance were awarded scholarships less frequently. Most scholarship holders studied in five academic centres: Warsaw, Cracow, Poznań, Lublin and Wrocław.

Shortly before Poland's accession to2 the EU structures, since the academic year 2002/2003 there was an increase in the number of students from Russia starting education at Polish universities without scholarships and free of charge. By contrast, starting from the academic year 2009/2010 there was a rise in the number of Russian students who began paid-for university studies. In the last year investigated, 2013/2014, students who began university courses free of charge accounted for $23.2 \%$ and those paying for their studies $-64.9 \%$ of the overall number of students from Russia.

\section{Conclusion}

Students from Russia have been coming to Poland since the early 1990s. Russian citizens took up education in Poland on the basis of bilateral agreements. Until mid-1990s they used to cross the Polish borders without a visa granting the right to study; later the situation began to change when Polish authorities started to enforce the law. Russians accounted for a small percentage of foreign nationals studying in Poland. In the academic year 1993/1994 they constituted slightly more than 1\%, and in the final year investigated - 2014/2015 - a mere $2 \%$. In the first year analysed all students from Russia received scholarships from the government of the Republic of Poland. The number of students arriving in Poland increased over time. The number of those awarded scholarships rose proportionally. Shortly before Poland's accession to the EU structures there was a visible increase in the number of Russian citizens studying without a scholarship and free of charge. In the last academic year investigated those paying for their studies constituted the largest group of students.

\section{References}

Act of 12 December 2013 on foreign nationals, Journal of Laws of 2013, item 1650.

Act on higher education of 27 July 2005, Journal of Laws No. 164, item 1365, as amended.

Agreement between the Government of the Polish People's Republic and the Government of the Union of Soviet Socialist Republics on the equivalence of documents concerning education and academic degrees and titles awarded in PPR and USSR, signed on 10 May 1974. Journal of Laws of 1975 No. 4, item 14.

Agreement between the Government of the Government of the Republic of Poland and the Government of the Russian Federation on cooperation in the fields of culture, science and education, Journal of Laws of 1994 No. 36, item 133.

Convention on mutual recognition of equivalence of documents certifying the completion of primary, secondary, secondary vocational and tertiary education and documents awarding academic degrees and tiles signed in Prague on 07 June 1972, Journal of Laws of 1973 No. 5, item 27.

Lane Kirkland Scholarship Programme. Statistics [online] Available http://www.kirkland.edu.pl/pl_(31.03.2015).

Małyszko J., (2005). Początki kształcenia w Polsce młodzieży polskiej z Wschodu. Studenci absolwenci uczelni polskich pochodzący z Litwy, Białorusi i Ukrainy (Polish University graduates from Lithuania, Belarus and Ukraine), [in:] Mniejszość polska na rozdrożu, ed. R. Wyszyński, Institute of Sociology of the University of Warsaw, 25.

Materials from the Bureau for Academic Recognition and International Exchange (2015).

Ordinance of the Minister of National Education and Sport of 24 April 2002, Journal of Laws of 2002, No. 69, item 634.

Plan of Cooperation with the Polish Diaspora and Poles Abroad in 2014 (2013), Warsaw, p. 15

Protocol on cooperation between the Minister of Culture of the Republic of Poland and the Minister of Culture of the Russian Federation for 2002-2003 signed in Warsaw on 28 June 2002,Official Gazette of the Republic of Poland (M. P.) of 2003 No. 8, item 12.

Regulation of the Minister of Science and Higher Education of 09 September 2009 amending the Regulation on starting and completing of studies and training by foreign nationals and their participation in research and development activities, Journal of Laws of 2009 No. 176, item 1365.

Resolution No. 61 of the Council of Ministers of 26 March 2013 concerning the adoption of the "Social Capital Development Strategy 2020", Official Gazette of the Republic of Poland (M. P.) of 2013, item 376.

Scholarship offer of the Bureau for Academic Recognition and International Exchange for the academic year 2012/2013 (online) Available: http://www.p.lodz.pl/zalaczniki/10517,8811,buwiwm_-_oferta_na_2012-2013.pdf,63837.pdf (22.10.2015).

Stypendia dla studentów z krajów Partnerstwa Wschodniego [online] Âvailable http://www.go-poland.pl/pl/stypendia-dla-student-w-z-kraj- 
w-partnerstwa-wschodniego-oraz-z-kraj-w-postsowieckich (14.03.2015).

Szymański J (2015) Relacje traktatowe z Rosją po przystapieniu Polski do UE [online] Available http://repozytorium.uwb.edu.pl/jspui/ bitstream/11320/2757/1/BSP_9_2011_Szymanski_\%5B1\%5D.pdf (1.10.2015).

Treaty between the Republic of Poland and Russia made in Moscow on 22 May 1992, Journal of Laws of 1993 No. 61, item 201.

Wyszyński,R.,(2011). Koncepcje kształcenia elity polskiej na wschodzie: system stypendialny dla studentów polskich z krajów b. ZSRR (Schemes for the education of Polish elite in the East: the scholarship system for Polish students from former Soviet Republics), in: Polska Inteligencja na Wschodzie. Teraźniejszość i perspektywy M. Głowacka - Grajter (Ed.), ProLog Warsaw, 124. 